\title{
THE URGENCY OF IMPLEMENTING SOME OF THE EFFECTIVE ARABIC LEARNING METHODS TO IMPROVE THE STUDENTS” ABILITY TO READ “KITAB KUNING” OF PBA FTIK PROGRAM OF IAIN PALU
}

\author{
Ahmad Asse, Ahmad Sehri, dan M. Asy'ari \\ IAIN Palu, Sulawesi Tengah \\ Email: asyari1204@gmail.com
}

\begin{abstract}
Abstrak
Penelitian ini berfokus, bagaimana penerapan beberapa metode pembelajaran bahasa Arab yang efektif dalam meningkataan kemampuan membaca kitab kuning pada mahasiswa Prodi PBA FTIK IAIN Palu. Penelitian ini merupakan penelitian lapangan (field research) yang memberikan gambaran situasi dan kejadian secara sistematis, utuh serta aktual, mengenai faktor-faktor dan sifatsifat yang saling mempengaruhi, serta menjelaskan hubungan dari permasalahan yang sedang diteliti. Teknik pengumpulan data dengan studi lapangan, wawancara mendalam dan observasi. Data yang didapat di lapangan kemudian dianalisis dan disusun dalam draft tanya jawab antara peneliti yang kemudian membuat kesimpulan umum untuk dilaporkan sebagai hasil dari penelitian yang telah dilakukan. Hasil dari penelitian ini menunjukkan bahwa penerapan beberapa metode di kalangan mahasiswa IAIN Palu tidak berjalan dengan efektif kecuali metode qawaid tarjamah, sebagaimana yang diamanatkan dalam kurikulum tahun 1998. Tidak adanya titik temu antara kurikulum dan pelaksana kurikulum dalam hal ini dosen yang menjadi faktor utama tidak terselenggaranya metode tersebut sesuai dengan harapan. Sedangkan metode qawaid tarjamah lebih efektif dibanding metode lainnya. Selain itu, keterampilan berbahasa dan membaca kitab kuning yang dimiliki oleh mahasiswa IAIN Palu sangat dibawa standar walaupun metode qawaid tarjamah sangat berpengaruah tapi tidak maksimal, ini diakibatkan oleh penerapan metode langsung yang menggunakan teori nazariyah al-wahdah, namun tidak terdapat kemantapan dalam membaca dan menerjemah.
\end{abstract}

Kata Kunci :Metode Pembelajaran, Bahasa Arab, Kitab Kuning.

\begin{abstract}
This research is focused, how to apply several effective Arabic learning methods in improving the ability to read the Kitab Kuning to the Students PBA IAIN Palu. This research is a field research, which provides a systematic description of situations and events, intact and actual, and explain the relationship of the problem being studied. Data collection techniques with field studies, in-depth interviews and observations. The data obtained in the field are then analyzed and compiled in a draft question and answer between the
\end{abstract}




\section{Fitrah \\ $\triangle$ Jurnal Kajian Ilmu-ilmu Keislaman \\ Vol. 6 No. 1 June 2020}

researchers who then make general conclusions to be reported as a result of the research that has been done. The results of this study indicate that the application of several methods among the students of IAIN Palu is not effective except for the qawaid tarjamah method, as mandated in the 1998 curriculum. There is no meeting point between the curriculum and curriculum implementers, in this case the lecturers who are the main factor in not implementing the method according to expectations. While the qawaid tarjamah method is more effective than other methods. In addition, the language skills and reading of the Kitab Kuning owned by IAIN Palu students are very standardized even though the qawaid tarjamah method is very fruitful but not optimal. This is due to the application of the direct method using the Nazariyah al-Wahdah theory, but there is no stability in reading and translating.

Keywords: Learning Methods, Arabic, Kitab Kuning

\section{INTRODUCTION}

Language has a major feature in human life and has been studied since time immemorial, especially the language of the family which is needed to communicate with people around it, or in other words, to be able to live as a social being, language is a primordial tool in communicating. (Ubadah, 2016) Even in the Koran it says wa 'allama adam al asmaa kullaha, which means more or less that God has taught "language" to Adam. In learning language in this context, according to Subyakto, no one can be called a teacher in the usual sense, so that the procession cannot be called "teaching" language. (Subyakto, 1993, p. 1)

Learning a foreign language, including Arabic, will be more difficult to understand than the mother tongue, because, apart from the vocabulary that is rarely used, the structure of words and sentences also takes a special time to learn. Therefore, teaching foreign languages in formal and informal institutions requires appropriate teaching methods in accordance with the general objectives of teaching the language itself.(Pambudi, 2014) The term that is often used in learning a language that is not the first language or mother tongue is learning a second language or a foreign language (second language learning). In learning Arabic, a teacher is needed in the learning process. In the teachinglearning process, it is necessary to develop a method that commonly called a foreign language teaching methodology (Subyakto, 1993, p. 3). In the context of language teaching including Arabic teaching it cannot be said that there is a model and method that is superior to the others, because 
each model and method has theoretical and empirical grounds. However, in terms of improving reading Arabic texts there is a learning model that is more suitable and innovative (Hijriyah, 2018). Learning Arabic (foreign) is different from learning the mother tongue, therefore the basic principles of teaching must be different, both regarding the method (teaching model), the material as well as the process of implementing the teaching. The skill of mastery Arabic include listening competence (maharah alIstima'), speaking competence / maarah al-takallum, reading competence / maharah al-qira'ah), and writing skills ( writing competence / maharah al Kitaabah) (Ubadah, 2016).

Basically every human has the ability to mastery every language, although in different levels and urges. The differences among these are the teaching goals to be achieved, the basic abilities possessed, the motivation that is within and the interests and persistence. (Al-Ushaili, 2009, pp. 101105)

Arabic language, which has been recognized by the world as an international language, will certainly have a significant role in improvisation and competition at the international level. This is not only in the aspect of language development and linguistic science, but more than that, namely improvisation in the methodology sector and learning techniques.(Zulhannan, 2014, p. 3) This statement can certainly be proven concretely and factually in the Arabic learning process, where recently there have been many interactive and innovative Arabic learning models and techniques which will certainly increase the enthusiasm of students in learning Arabic simultaneously and continuously. It must be welcomed by Arabic language educators to be realized actively and creatively, so that the Arabic learning process takes place optimally and is integrated in the learning objectives to be achieved. In relation to this context, the author will conduct research on the existence of the qawaid wa altarjamah method or the translated grammatical method in Arabic learning at the Arabic Education Department, Tarbiyah Faculty and Teacher Training, IAIN Palu. 


\section{Fitrah \\ I Jurnal Kajian Ilmu-ilmu Keislaman \\ Vol. 6 No. 1 June 2020}

\section{RESEARCH METHODOLOGY}

This study focuses on describing effective Arabic learning techniques that can improve students' ability to read Arabic texts or texts without punctuation at the Tarbiyah and Teaching Sciences Faculty of Arabic Language Education, IAIN Palu. In this study, the researcher himself became the key instrument in describing and analyzing the application of Arabic learning methods by Arabic language lecturers in the PBA Department.

This research was conducted at IAIN Palu at Tarbiyah Faculty. The location selection was based on the consideration that based on the author's observations, the Arabic learning process at IAIN Palu with various problems was in the Arabic Language Education Department. The data collection techniques commonly used in qualitative research are observation or observation, interviews, and documentation techniques.

The context of data analysis in this study is the process of finding and organizing data regarding learning techniques in improving students' ability to read Arabic texts or texts in the PBA Department, systematically based on the results of observations, interviews, and documentation. The data that has been obtained from the research location is very important to be checked again, in order to really obtain accurate data as expected.(Nurhidayah et al., 2020) Checking the accuracy or validity of research data is a demand for scientific procedures, so that the conclusions obtained are truly objective and credible.

\section{THEORETICAL DESCRIPTION}

\section{Arabic as a medium for understanding religion}

This second form of learning Arabic grows and develops in various salaf Islamic boarding schools. The material taught includes fiqh, aqidah, morality, hadith, interpretation, and Arabic sciences such as nahwu, sharaf and balaghah with Arabic textbooks written by scholars from various centuries in the past. The learning method used in the second form is the grammatical-tarjamah method (tariqah al-qawa'id wa altarjamah / grammar-translation method) with a presentation technique that is still relatively traditional, in which the teacher or kyai and students (santri) respectively each holding a book (Herdah, 2017). The teacher reads 
and interprets word by word or sentence by sentence into the mother tongue or regional language that has been brought closer to the sensitivity of Arabic. Meanwhile, Arabic grammar (qawa'id) is inserted into certain words as symbols that indicate the function of a word in a sentence (Hanifah, 2012).

Santri only recorded the meaning of each Arabic word or sentence pronounced by the teacher, without active and productive verbal interaction between the teacher or kiai and the students (Zulhannan, 2014, p. 3). Among the textbooks or books written by Ulama from various centuries commonly used especially in teaching Arabic are Matan Aljurumiyah, Syarah Aljurumiyah, Kawakib Al-Durriyah, Alfiyah Ibn Malik, Al-Sharf, Arudh al-Qawafiy, Jawahir al-Balaghah.

\section{Arabic as a means of communication.}

Learning Arabic in modern Islamic colleges does not only use direct methods but follows updates that occur in the world of language learning, for example the aural-oral method (al-thariqah al-sam'iyah al-syafawiyah) and the communicative approach ( al-thariqah al-itthishaliyah) (Effendy, 2012).

\section{Effective Methods In Learning Arabic}

In simple terms, Arabic teaching methods can be classified into two types, namely: first, traditional / classical methods and second, modern methods. The traditional Arabic teaching method is an Arabic teaching method that focuses on "language as a culture of knowledge" so learning Arabic means learning deeply about the intricacies of Arabic, both grammatical/syntactic aspects (qawaid al-nahwu), morpheme/morphology, (qawaid al-sharf) or literature (adab). The methods that have been developed and well-known for this purpose are the methods of qawaid and tarjamah. This method has been able to last for several centuries, even today the pesantren in Indonesia, especially the salafiah pesantren, still apply this method. This is based on the following points: First, the aim of teaching Arabic seems to be in the cultural / scientific aspects, especially nahwu and sharaf. The second skill of nahwu science is considered an absolute requirement as a tool for understanding classical Arabic texts / words that 


\section{Fitrah \\ I Jurnal Kajian Ilmu-ilmu Keislaman \\ Vol. 6 No. 1 June 2020}

do not use vowels and other punctuation marks. Third, this field is a hereditary tradition, so that the ability in that field gives them "selfconfidence (prestige) among them". Modern Arabic teaching methods are goal-oriented teaching methods of language as a tool (Ahmad, 1983, p. 5) (al-Khalifah, 2004, p. 17). This means that Arabic is seen as a means of communication in modern life, so that the essence of learning Arabic is the ability to use the language actively and be able to understand words / expressions in Arabic. The method commonly used in teaching is the direct method (tariqah al-mubasyirah). The emergence of this method is based on the assumption that language is a living thing, therefore it must be continuously communicated and trained as young children learn languages (Thuaimah, 2010, p. 610).

Arabic language is communication in modern life, so the essence of learning Arabic is the ability to use the language actively and can be able to understand words / expressions in Arabic. The method commonly used in teaching is the direct method (tariqah al-mubasyirah). The emergence of this method is based on the assumption that language is a living thing, therefore it must be continuously communicated and trained as young children learn languages.

\section{Innovative Arabic Learning Principles and Systems}

Almost of languages in this world have elements that can be seen separately even though they are closely related and unite to form a phenomenon called language. In addition, performance and language skills also vary, some are in oral form and some are in written form. There are those who are receptive (listening and reading), and also those that are productive (speaking and writing). In language learning, there are several systems, integrated, separate, and combined, as has been discussed in the emergence or growth of history in the previous sub-chapter. 


\section{RESEARCH RESULTS AND DISCUSSION}

Application of the Qawaid and Tarjamah Methods which are considered the Most Effective in Improving the Ability to Read the Kitab Kuning.

There are four components that support each other and play an important role to improving Arabic learning in an educational institution. The four components are curriculum, teaching staff, teaching, and students (Sujana, 1995, p. 1).

a. Teaching

In every language there are elements that can be seen separately even though they are closely related to each other and even unite to form a phenomenon called language. Performance and language skills also vary. Some are in oral form and some are in written form. Some are receptive (listening and reading) and some are productive (speaking and writing). There are various systems in teaching language elements and language skills, namely segregated systems, integrated systems and combined systems.

b. Curriculum

Looking at the curriculum that is used as a practice and reference in carrying out learning, including the teaching and learning process of Arabic at IAIN Palu, seems to be directing these activities to the implementation and application of the translated qawaid method. In accordance with the observations of the authors in all majors and study programs in this institution, they used the 1998 curriculum, especially for learning Arabic the writer will display these ideas as follows:

This course is designed to know the students deeps and outs of Arabic, especially the grammatical aspects. After attending this course, students will have the basic skills to understand Arabic texts, read them well and correctly, analyze words, sentence structures and so on. Paying attention to the directions from the above quote shows that the goals and objectives of learning Arabic to be achieved are so that students have the skills to read Arabic texts, which leads to the ability to understand and translate them into good and correct Indonesian. 


\section{Fitrah \\ $\Rightarrow$ Jurnal Kajian Ilmu-ilmu Keislaman}

Vol. 6 No. 1 June 2020

c. The Topics of Learning Arabic

To improve reading mastery of the Kitab Kuning in Arabic learning, there are several topics as follows:

\begin{tabular}{|c|c|}
\hline 22. أسماء الاستفهام & 1. مقدة : اللغة العربية و علومها \\
\hline المعرفة و النكرة .23 & 2. الكلمة و أقسامها \\
\hline 24 المقترن بـ "أل" & 3. الجملة و أنواعها \\
\hline 25 المنادى المقصود 25 & 4. الإعراب و البناء \\
\hline المصدر و أنواعه .26 & 5. الفعل و أقسامه \\
\hline 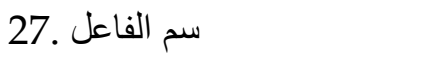 & 6. الماضى و المضارع و الأمر \\
\hline 28. الصفة المشبهة & 7. الغعل المتعدى \\
\hline 29. اسم التفضيل & 8. الفعل اللازم \\
\hline أسماء الزمان .30 أ3 & 9. المعلوم و المجهول \\
\hline 31. اسم الآلة & 10. الصحيح و المعتل \\
\hline الجمع و أنو اعه .32 & الفعل الجامد .11 الف \\
\hline كن و أخواتها .33 & أفعال التعجب .12 \\
\hline إن و أخو اتها .34 إن & أفعال المدح و الذم .13 \\
\hline المصدر الصريح و المؤول .35 & الفعل المتصرف .14 \\
\hline 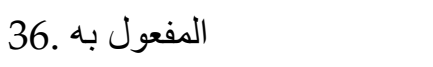 & نونات التوكيد مع الفعل .15 \\
\hline 37. المفعول المطلق & الاسم و أقسامه .16 \\
\hline المفعول لأجله .38 & الموصوف و الصفة .17 \\
\hline المفعول فيه .39 & 18. المذكر و المؤمث \\
\hline المفعول معه .40 & الضمائر و أنو اعها .19 \\
\hline 41. اسم المفعول & 20. أسماء الإشارة \\
\hline 42. الإضافة & 21. الأسماء الموصول. \\
\hline
\end{tabular}

From these topics, it is not analyzed in detail but it can be understood that the target of discussion in these topics is closely related to efforts to increase mastery of reading the Kitab Kuning because in essence there is a study of i'rab and rules in learning Arabic which is concerning the problem of grammar or descriptions that have a lot to do with Qawaid. The Arabic learning is grouped into two groups, the first is national with a weight of 6 credits and distributed into two semesters, each semester totaling 3 credits. And the second is local, the number of credits varies in each department, 
depending on the needs and the results of the formulation at the level of each department.

d. Lecturer

Lecturers is a central position, because their role is very decisive. He must be able to interpret and translate and describe the values contained in the curriculum, then transform these values to students through the teaching and learning process in the classroom. Lecturers are not encouraged to make and arrange curriculum, but they are users and users of the curriculum. Teachers who have the confidence to teach Arabic courses at IAIN Palu can be said that they have a scientific background in the field of Arabic. They passed Arabic literature and language and Arabic education, even them there were alumni of Al-Azhar University in Egypt and Khurtum University of Sudan. Arabic lecturers can be divided into two groups. the first group is those who are experts in the field of Arabic because they are appointed as civil servants / lecturers in the field, they are considered permanent lecturers in Arabic courses. The second group of those who have proficiency in the field of Arabic but have been appointed as civil servants / lecturers fostering other subjects, they are considered non-permanent lecturers in Arabic.

\section{Achievement of Language Skills and Ability to Read the Kitab Kuning}

Language skills are a general goal of learning a language, including Arabic. These skills include: Writing, reading, speaking, and listening skills commonly referred to as almaharatul arba' as follows:

a. Writing

Writing in the strict sense is limited to copying or writing only spelling. In a broad sense, it means that besides the narrow understanding above, it is also added in the writing process which requires intellectual thought which should reveal the heart's contents. The term popular writing in Indonesian with the term concocted. Of course this understanding is too deep for students who are not Arabic language education courses. Of course what is meant here is the writing skill is someone who has the Arabic writing skills properly and correctly. 


\section{Fitrah \\ $\triangle$ Jurnal Kajian Ilmu-ilmu Keislaman \\ Vol. 6 No. 1 June 2020}

b. Reading

The definition of reading is an activity that includes, patterns of thought, assessment, analysis, and problem solving. In reading. A person's personality with everything involved. One of the functions of reading Arabic is to make it the key to unlocking Islamic knowledge and culture. The minimum required reading ability for students is to read books that do not have a community, accompanied by understanding and in turn they can be translated. Its purpose is to know what kind of skills do IAIN Palu students have.

c. Speaking

What is meant by speaking is to pronounce the sounds of the Arabic language correctly according to the terms and rules of that language. The speaking skill is to speak fluently without stuttering and not repeating vocabulary and in a loose voice. A student who is skilled at speaking means that he is able to achieve the main language learning targets. Speaking in a second language is a major skill which is also one of the ultimate goals of language study.

d. Listening

Listening is an activity that is carried out consciously and deliberately and responds immediately to what one hears. Understanding and fully capturing what is heard from speakers of these languages, either directly or indirectly, is a language skill and students of IAIN Palu have to participate in the Arabic learning process.

\section{Supporting and Inhibiting Factors of the Application of the Translated Qawaid Method as the Most Effective Method to Increase Mastery of Reading the Kitab Kuning}

1. Support

a. The heads of the department gave a positive appreciation of learning Arabic by allocating a sufficient number of credits for learning Arabic.

b. The language service unit also has a number of learning activities, in addition to English language learning, Arabic lessons are also 
scheduled, such as practicum Arabic language courses, and language environment.

c. The attention of most lecturers still wants the application of the qawaid-translation method to be applied among students, provided that the new format is used so that it is not burdensome for students to understand it.

Table 15

Perception Of Lecturers About No Need To Apply The QawaidTranslated Method (Not Contemporary)

\begin{tabular}{|c|c|c|c|c|c|}
\hline No & Optimal & weight & Frequency & Total & Information \\
\hline 1. & a. & 5 & - & - & - \\
\hline 2. & b. & 4 & 2 & 8 & $21 \%$ \\
\hline 3. & c. & 3 & 9 & 27 & $71 \%$ \\
\hline 4. & d. & 2 & 1 & 2 & $5.3 \%$ \\
\hline 5. & e. & 1 & 1 & 1 & $2.6 \%$ \\
\hline \multicolumn{2}{|c|}{ total } & & 13 & 38 & $99.9 \%$ \\
\hline
\end{tabular}

From the data proves that $56.5 \%$ of the lecturers want this method to be applied, only $44.5 \%$ stated otherwise.

d. Students' interest in Arabic has not faded, they still state the need to learn Arabic, even though there are books in Indonesian that can be used as reference material.

Table 16

Perception of MAH. Concerning Not Interest In Arabic

\begin{tabular}{|c|c|c|c|c|c|}
\hline No & Optimal & Weight & Frequency & Total & Information \\
\hline 1. & a. & 5 & - & - & - \\
\hline 2. & b. & 4 & 4 & 16 & $23.5 \%$ \\
\hline 3. & c. & 3 & 13 & 39 & $57.3 \%$ \\
\hline
\end{tabular}


Vol. 6 No. 1 June 2020

\begin{tabular}{|c|c|c|c|c|c|}
\hline No & Optimal & Weight & Frequency & Total & Information \\
\hline 4. & d. & 2 & 6 & 12 & $17.6 \%$ \\
\hline 5. & e. & 1 & 1 & 1 & $1.5 \%$ \\
\hline \multicolumn{2}{|c|}{ Total } & 24 & 68 & $100 \%$ \\
\hline
\end{tabular}

The data above proves that $80.8 \%$ of students are still interested in Arabic.

e. Blockers

1) There is no meeting point between the curriculum and implementation in the field regarding the use of a method, as a result, does not send the material to students without referring to certain references.

2) The student recruitment which is varied makes it difficult to determine the selection of the application of a method that is considered suitable and in accordance with the conditions of students as consumers.

Table 17

Perception of MAH. About Arabic Materials (Too High)

\begin{tabular}{|c|c|c|c|c|c|}
\hline No & Optimal & Weight & Frequency & Total & Info \\
\hline 1. & a. & 5 & 2 & 10 & $12.3 \%$ \\
\hline 2. & b. & 4 & 13 & 36 & $44.4 \%$ \\
\hline 3. & c. & 3 & 6 & 30 & $37 . \%$ \\
\hline 4. & d. & 2 & 2 & 4 & $4.9 \%$ \\
\hline 5. & e. & 1 & 1 & 1 & $1.2 \%$ \\
\hline & \multicolumn{2}{|c|}{ Total } & 24 & 81 & $99.8 \%$ \\
\hline
\end{tabular}

The table above illustrates the number of students overvaluing material around $56.7 \%$ which states the opposite is $6.1 \%$ and which states it is less true $37 . \%$. 
Table 18

Perception of MAH. About Arabic Materials (Too Low)

\begin{tabular}{|c|c|c|c|c|c|}
\hline No & Optimal & weight & Frequency & Total & Info \\
\hline 1. & a. & 5 & 2 & 10 & $11.8 \%$ \\
\hline 2. & b. & 4 & 13 & 52 & $61.2 \%$ \\
\hline 3. & c. & 3 & 6 & 18 & $21.2 \%$ \\
\hline 4. & d. & 2 & 2 & 4 & $4.7 \%$ \\
\hline 5. & e. & 1 & 1 & 1 & $1.2 \%$ \\
\hline & & Total & 24 & 85 & $100.1 \%$ \\
\hline
\end{tabular}

The table above illustrates that the majority of students stated that the material received was very low, reaching $73 \%$, on the contrary $5.9 \%$ stated that it was not low, and $21.2 \%$ stated that the material received was simple.

Differences in students' understanding of the material, should be guessed because of the unequal background of language capital. Those who say it is difficult may be students who come from public schools, and those who say easy are those from Madrasah Aliyah.

3) There is no clear determination regarding the boundaries and levels of Arabic learning material, for example: Arabic I this material, Arabic II this material, and so on, as a result learning becomes unsustainable, not organized in such a way.

f. The solution

To the solution To solve existing problems, it is necessary to take several steps as follows:

1) Bringing together curriculum directions in Arabic learning with the use of the curriculum, in this case Arabic language lecturers, so that there is uniformity in the learning process.

2) There is a need for certain classes for prospective students or students with a high school education background and the like, so that there is special coaching in learning Arabic. 
3) As early as possible, a sympusium, workshop or the like is held, driven by the institution to define and realize the boundaries of Arabic language material, starting from Arabic 1, Arabic II and so on.

\section{CONCLUSION}

This study indicated that the application of several methods among the students of IAIN Palu is not effective except for the qawaid tarjamah method, as mandated in the 1998 curriculum. There is no meeting point between the curriculum and curriculum implementers, in this case the lecturers who are the main factor in not implementing the method according to expectations. While the qawaid tarjamah method is more effective than other methods. In addition, the language skills and reading of the Kitab Kuning owned by IAIN Palu students are very standardized even though the qawaid tarjamah method is very fruitful but not optimal. This is due to the application of the direct method using the Nazariyah al-Wahdah theory, but there is no stability in reading and translating. 
The Urgency of Implementing Some of The Effective Arabic.... Ahmad Asse, dkk

DOI: $h$ ttp://dx.doi.org/10.24952/fitrah.v6i1.2695

\section{REFERENCES}

Ahmad, M. A. Q. (1983). Thurqu Ta'lim al-Lughah al-'Arabiyah. Al-Maktabah alAmawiyyah.

al-Khalifah, H. J. (2004). Fushul fi Tadris al-Lughah al-"Arabiyah. Maktabah Rusydi.

Al-Ushaili, A. A. bin I. (2009). Psikolinguistik Pembelajaran Bahasa Arab. Humanora.

Effendy, A. F. (2012). Metodologi Pengajaran Bahasa Arab. Penerbit Musykat.

Hanifah, U. (2012). طريقة القو اعد والترجمة في تعليم اللغة العربية و تطبيقها. Nun Wa Al-Qalam, 06(02), 1-12.

Herdah, H. (2017). Penerapan Model Pembelajaran Kolaborasi dan Elaborasi dan Pengaruhnya terhadap Sikap Belajar Bahasa Arab Mahasiswa (Studi Eksprimen pada Program Studi Tadris Bahasa Inggris Sekolah Tinggi Agama Islam Negeri (STAIN) Parepare) [Doctoral, Universitas Islam Negeri Alauddin Makassar]. http://repositori.uin-alauddin.ac.id/13143/

Hijriyah, U. (2018). Analisis Pembelajaran Mufrodat Dan Struktur Bahasa Arab Di Madrasah Ibtidaiyah (S. Syarief, N. Nu'man, \& M. Mahdi, Eds.). CV. Gemilang Media Pradaban Gemilang. http://repository.radenintan.ac.id/3266/

Nurhidayah, N., Jabir, M., \& Rus'an, R. (2020). Studi Analisis Kemampuan Mengenal Huruf Hijaiyah Pada Anak Usia Dini Melalui Bermain Puzzle Di Kelompok B TK AL-KHAIRAAT Kabonena Kota Palu. Ana' Bulava: Jurnal Pendidikan Anak, 1(1), 53-62. https://doi.org/10.24239/abulava.Vol1.Iss1.4

Pambudi, K. (2014). Pengaruh Pelaksanaan Praktek Muhadhasah Pagi Terhadap Prestasi Belajar PAI (Materi Al-Qur'an Hadits) Siswa di SMP Plus Ar-Rahmat Bojonegoro [Undergraduate, UIN Sunan Ampel Surabaya]. http://digilib.uinsby.ac.id/820/

Subyakto, S. U. (1993). Metodologi Pengajaran Bahasa. Gramedia Pustaka Utama.

Sujana, N. (1995). Dasar-Dasar Proses Belajar Mengajar. Sinar Baru Algensido.

Thuaimah, R. A. (2010). Al-Marja' fi Ta'lim al-Lughah al-'Arabiyah. Jamiah Umm alQura. 


\section{Fitrah \\ $\triangle$ Jurnal Kajian Ilmu-ilmu Keislaman}

Vol. 6 No. 1 June 2020

Ubadah. (2016). Metode Pembelajaran Bahasa Arab Yang Efektif Untuk Meningkatkan Kemampuan Bercakap Mahasiswa FTIK IAIN (Studi pada Jurusan Pendidikan Bahasa Arab). ISTIQRA: Jurnal Penelitian Ilmiah, 4(1). https://www.jurnal.iainpalu.ac.id/index.php/ist/article/view/204

Zulhannan. (2014). Teknik Pembelajaran Bahasa Arab Interaktif. Raja Grafindo Persada. 